\title{
KELUARGA, KONTROL SOSIAL, DAN "STRAIN" : MODEL KONTINUITAS DELINQUENCY REMAJA
}

\author{
Eny Purwandari \\ Fakultas Psikologi \\ Universitas Muhammadiyah Surakarta \\ Jalan Ahmad Yani Tromol Pos 1 Pabelan Surakarta \\ rajen_bila@yahoo.com
}

\begin{abstract}
Behavior emerges from a continuous process, which begins with the individual's perception, internalization of the concept, to the covert behavior. Behavior is the result of experience. This study aims to test models of delinquency. Delinquency as a continuous learning process of behavior from mild to serious. The subjects were junior and high school students as many as 182 people from 3 schools that obtained by random. The data were analyzed using structural equation modeling (SEM) showed that delinquency was a behavior that basically formed an ongoing basis. Families have the highest impact when compared with peers and the media. Conditions will be worsened if the child has a 'strain' in delinquency bring light and progress to serious delinquency.
\end{abstract}

Keywords: Delinquency, Family, Peer, Media, Social Control, Strain.

\begin{abstract}
Abstrak
Perilaku munculdari sebuah proses yang berkelanjutan, yang berawal dari persepsi individu, internalisasi konsep, sampai pada perilaku yang terlihat. Perilaku merupakan hasil dari belajar dari pengalaman. Penelitian ini bertujuan untuk uji model delinquency. Delinquency sebagai perilaku proses berkelanjutan dari ringan sampai berat. Subjek penelitian adalah siswa SMP dan SMA sebanyak 182 orang dari 3 sekolah yang diperoleh dengan random. Data yang dianalisis dengan structural equation modeling (SEM) diperoleh hasil bahwa delinquency merupakan perilaku yang pada dasarnya terbentuk secara berkelanjutan. Keluarga mempunyai pengaruh paling tinggi apabila dibandingkan dengan teman sebaya dan media. Kondisi akan diperparah apabila anak mengalami "strain" di dalam memunculkan
\end{abstract}


delinquency ringan dan berlanjut menjadi delinquency yang berat.

Kata kunci: delinquency, Keluarga, Kontrol Sosial, Strain, Teman Sebaya.

\section{Pendahuluan}

Problem utama remaja yang disinyalir berkaitan dengan kesehatan mental dan terkait dengan perilaku nakal adalah merokok, penyalahguna napza, alkohol, dan obat-obatan. Ketiganya berkaitan dan seringkali menjadi satu kesatuan problem yang serius. Penyalahguna napza amat memprihatinkan karena sebagian besar diderita oleh generasi muda yang umumnya berusia 15-24 tahun, dan banyak yang masih aktif di SMP, SMA, maupun perguruan tinggi. Secara umum pengguna pertama NAPZA diawali pada anak yang relatif muda (Purwandari 2007).

Subjek mantan penyalahguna napza menyatakan bahwa teman sebagai salah satu objek lekat anak yang dapat mempengaruhi perilaku, dalam hal ini adalah penyalahgunaan napza, yang tergolong bentuk delinquency (Purwandari 2007). Seperti yang dikatakan oleh Hircshi (dalam Mason \& Windle, 2002) dengan teori bonding-nya yang menyatakan bahwa objek lekat anak adalah peers (teman), sekolah, dan keluarga. Keluarga pada anak rentang $11 \quad 19$ tahun kurang mempunyai kelekatan yang tinggi, sehingga anak lebih dekat dengan temannya apabila dibandingkan dengan keluarga. Selain itu delinquency pada bentuk penyalahgunaan napza dengan umur yang relatif muda (11 tahun) akan lebih lama mengalami delinquency.

Penyalahguna napza yang sedang menjalani program rehabilitasi di sebuah lembaga memiliki sejumlah alasan untuk merasionalisasi penggunaan napza, seperti menambah keberanian dan kreativitas, menghindari masalah, frustrasi, kesepian, atau memenuhi rasa ingin tahu (Purwandari, 2005). Ikut-ikutan teman prosentase paling besar sebagai alasan mereka. Hal ini sejalan paparan pada tabel 1.

Remaja yang telah terjerumus pada salah satu bentuk delinquency akan muncul bentuk delinquency lain (Booth, Farrell \& Varano, 2008). Contoh kasus pada hasil temuan Anganthi, Purwandari, dan Purwanto (2010) tentang napza. Penyalahgunaan napza adalah bentuk delinquency, namun juga terdapat bentuk delinquency lain

Sebanyak 71 subjek penyalahguna napza, memaparkan tentang perilaku delinquency yang dilakukannya selama satu bulan terakhir (Anganthi, dkk, 2010). Hasil analisis menunjukkan bahwa pada perkembangan usia remaja awal, perilaku 
menyontek dilakukan karena mereka masih duduk di bangku pendidikan. Kondisi memprihatinkan adalah ketika sudah melakukan perilaku mabuk-mabukan. Perbandingan pola delinquency yang tampak menyolok adalah frekuensi perilaku delinquency yang dilakukan antara usia remaja awal dan remaja akhir. Pada usia remaja akhir lebih banyak dilakukan dibandingkan dengan remaja awal. Hal yang menarik dapat dikaji berdasarkan data tersebut. Berdasarkan proses social learning theory Bandura yang menyatakan bahwa perilaku berasal daribelajar pengalaman, mendapat penguatan dan sudah menjadi kebiasaan. Padahal perilaku-perilaku tersebut jelas melanggar norma dan aturan yang berlaku pada setting masing-masing. Misalnya menyontek merupakan pelanggaran dari aturan sekolah, mabuk melanggar norma hukum dan sosial. Hasil lain dari Anganthi, Purwandari, dan Purwanto (2010) juga dipaparkan pada tabel 1 di bawah ini.

Tabel 1.

Pola Perilaku Delinkuency Remaja Ditinjau dari Jenis Kelamin

(Anganthi, Purwandari, dan Purwanto, 2010)

\begin{tabular}{cccccccc}
\hline \multicolumn{4}{c}{ LAKI-LAKI } & \multicolumn{5}{c}{ PEREMPUAN } \\
\hline No & $\begin{array}{c}\text { Perilaku } \\
\text { Delinkuensi }\end{array}$ & Item & $\begin{array}{c}\text { Frek } \\
\text { Perilaku }\end{array}$ & No & $\begin{array}{c}\text { Perilaku } \\
\text { Delinkuensi }\end{array}$ & Item & $\begin{array}{c}\text { Frek } \\
\text { Perilaku }\end{array}$ \\
\hline 1 & Mencontek & 8 & 112 & 1 & Mencontek & 8 & 30 \\
2 & Mabuk & 10 & 108 & 2 & Berbuat jahil & 2 & 24 \\
3 & Berbuat jahil & 2 & 104 & 3 & Mabuk & 10 & 21 \\
4 & Berjudi & 9 & 73 & 4 & Corat-coret & 1 & 15 \\
5 & Berkelahi & 7 & 71 & 5 & Berkelahi & 7 & 15 \\
6 & Corat-coret & 1 & 70 & 6 & Memalak & 6 & 13 \\
7 & Kebut-kebutan & 5 & 62 & 7 & Mencuri & 14 & 8 \\
8 & Memalak & 6 & 57 & 8 & Kebut kebutan & 5 & 6 \\
9 & Melecehkan & 15 & 28 & 9 & Melecehkan & 15 & 4 \\
10 & Mencuri & 14 & 26 & 10 & Berjudi & 9 & 2 \\
11 & Menganiaya & 13 & 16 & 11 & Menganiaya & 13 & 1 \\
\hline
\end{tabular}

Tabel 1 memaparkan tentang pola perilaku delinquency ditinjau dari jenis kelamin. Bentuk delinquency penyalahguna napza sebanyak 71 orang dengan 79\% laki-laki dan $21 \%$ perempuan menunjukkan bahwa pada responden laki-laki lebih menunjukkan tingginya frekuensi delinquency yang dilakukan. Delinquency yang dilakukan anak laki-laki sangat menyolok tingginya, sehingga dapat disimpulkan perbedaan signifikan delinquency antara laki-laki dan perempuan. Hasil tersebut sesuai dengan temuan Tracy, Leonard, dan James (2009) yang menyatakan bahwa laki-laki lebih banyak melakukan pelanggaran yang serius, mengarah kejahatan, dan 
kronis, sedangkan perempuan lebih banyak melakukan pelanggaran kronis saja. Selain itu variasi delinquency juga berbeda antara responden pria dan wanita. Tracy, Leonard, dan James (2009) menegaskan tentang perbedaan jenis kelamin dalam perilaku delinquency, hampir semua dilakukan oleh laki-laki, sedangkan perempuan hanya melakukan pada kasus-kasus delinquency spesifik yang diulang-ulang.

Kasus delinquency pada laki-laki banyak dikaitkan dengan faktor keluarga, kawan, dan kondisi psikologis, seperti tingkat komunikasi dengan orang tua, serta komunikasi anak dengan lingkungan sekolah. Adapun karakteristik masa kanakkanak dan pengaruh saudara yang nakal lebih banyak dikaitkan dengan perilaku delinquency pada wanita.

Berdasarkan data-data tersebut di atas delinquency berbentuk kontinuitas, mulai dari yang paling ringan sampai yang berat. Seorang anak akan lebih sering melakukan delinquency ringan daripada yang yang lebih berat. Mencontek lebih sering dilakukan daripada memalak, memalak lebih sering dilakukan daripada mencuri, mencuri lebih sering daripada menganiaya.

Delinquency sebagai salah satu fenomena yang dapat dikaji secara sosiologi, biologi, psikologi maupun kriminologi. Delinquency merupakan sebuah perilaku, dengan kata lain merupakan produk dari proses mental. Secara umum, masyarakat menyebut delinquency sebagai kenakalan. Kenakalan adalah sebuah proses konformitas. Terdapat proses sosialisasi yang membentuk formasi individu yang sesuai dengan lingkungannya (Wiatrowski, Griswold, \& Roberts, 1981).

Sunarwiyati (dalam Masngudin, 2004) membagi kenakalan remaja kedalam tiga tingkatan; (1) kenakalan biasa, seperti suka berkelahi, sukakeluyuran, membolos sekolah, pergi dari rumah tanpa pamit (2) kenakalan yang menjurus pada pelanggaran dan kejahatan seperti mengendarai mobil tanpa SIM, mengambil barang orang tua tanpa izin (3) kenakalan khusus seperti penyalahgunaan narkotika, hubungan seks diluar nikah, pemerkosaan, dan lain-lain.

Ngai dan Cheung (2005) menyebutkan 12 bentuk delinquency, yaitu : bullying, mengendarai tanpa SIM, gang activity, serangan, perilaku anarkis (merusak), penipuan, pencurian, perkosaan, perilaku tidak senonoh, pemakaian heroin, pemaikaian psikotropikan, dan perampokan. Istilah penyalahgunaan napza dinyatakan sebagai salah satu bentuk delinquency (Cookston, J.T. 1999; Katz, Dunham, \& Zimmerman, 1997).

Teori delinquency dan masalah perilaku yang digunakan sebagai kerangka kerja untuk mengembangkan pengertian tentang delinquency yang akan mampu menggambarkan delinquency/problem behavior adalah social control theory dan 
general strain theory.

Social control theory (Hirschi dalam Wiatroswki, Griswold, \& Roberts, 1981; Wadsworth, 2000) menyebutkan adanya peran mikrosistem di dalam pembentukan delinquency anak. Asumsi teori ini adalah koneksi sosial antara anak dengan keluarga, teman, sekolah dan lingkungan sosial lain. Pada lingkungan sosial yang mikro tersebut menurut Ngai \& Cheung (2005); Wester, MacDonald, \& Lewis (2008) menyebutkan sebagai lingkungan eksternal dari anak dan diberlakukan aturan-aturan, values dan belief yang bersifat konvensional.

Hircshi s social control/bonding theory (Booth, Farrell, \& Varano, 2008; Wester, MacDonald, \& Lewis, 2008; Ingram, Patchin, McCluskey, \& Bynum, 2007; Mason \& Windle, 2002) menyebutkan empat elemen social bond, yakni

1. Attachment atau kelekatan.

Kelekatan merupakan faktor emosi. Hal ini mendeskripsikan bahwa anak memiliki kecenderungan untuk melekatkan diri pada orang lain. Anak melakukan kelekatan ini dengan orang tua, sekolah dan teman sebayanya, di dalamnya termasuk supervisi orang tua, kualitas komunikasi, kebersamaan, pemahaman orang tua tentang pertemanan anaknya dan kepercayaan. Jika kelekatan anak kuat terhadap pihak tertentu, hal ini akan membentuk suatu komintmen.

2. Commitment atau komitmen terhadap aturan.

Komitmen merupakan komponen rasional dari suatu ikatan. Hal ini mengacu pada sejauh mana anak-anak terlibat dalam kegiatan konvensional suatu kelompok. Komitmen seorang dengan tidak melakukan suatu tindakan pelanggaran dikarenakan mereka tahu mendapatkan masalah akan menghambat kesempatan mereka untuk menjadi sukses. Hal ini dapat terbentuk jika ada dalam kelompok dimana anak melekatkan dirinya. Contohnya seperti menghormati tradisi, dan percaya pada norma-norma dan nilai-nilai hidup yang berlaku di masyarakat.

3. Involvement atau keterlibatan.

Keterlibatan anak berhubungan dengan seberapa banyak waktu yang dihabiskan seorang anak untuk berinteraksi dengan individu lain dalam suatu kegiatan. Jika interaksi yang tepat dengan kegiatan maupun seseorang, seperti olah raga, kesenian dan lainnya merupakan kegiatan yang secara dominan dilakukan anak maka kemungkinan melakukan perilaku nakal akan semakin kecil. Namun sebaliknya jika interaksi dan kegiatan yang kurang tepat seperti bolos, tawuran, melawan orang tua, mencuri dan lainnya marupakan hal yang sering dilakukan anak maka kenakalan pun akan semakin mudah terbentuk dalam diri anak.

4. Belief atau keyakinan.

Keyakinan yaitu kesediaan dengan penuh kesadaran untuk menerima segala aturan. Keyakinan dalam nilai moral dari norma konvensional merupakan 
komponen keempat dari ikatan sosial. Beberapa anak memiliki keyakinan yang lebih kuat dalam mengikatkan diri dalam aturan social, sehingga tidak cenderung berkomitmen terhadap kenakalan.

Secara spesifik, social control theory menekankan adanya supervisi dan perilaku moral dapat diberikan oleh orang tua sehingga dapat mengurangi angka kenakalan. Studi yang dilakukan oleh Farrington, Loeber, Yin, and Anderson (dalam Wester, MacDonald, \& Lewis, 2008) pada 500 remaja melaporkan bahwa penyebab delinquency adalah rendahya supervisi orang tua, rendahnya apresiasi yang diberikan orang tua sebagai bentuk reinforcement, dan rendahnya keterlibatan dalam aktivitas kebersamaan.

Booth, Farrell, \& Varano (2008) memakai konsep dari social control theory untuk memprediksi delinquency yang serius dan yang beresiko delinquency. Delinquency yang serius seperti : kekerasan, perkelahian, pemakaian senjata dan delinquency beresiko tinggi adalah merokok, minuman keras, mengemudi dengan mabuk. Jenis kelamin dan tingkat pendidikan dapat dijadikan salah satu pertimbangan di dalam prediksi delinquency. Pada hasil Booth, Farrell, \& Varano (2008) tersebut yang lebih dominan dalam prediksi delinquency adalah involvement dalam setting mikrosistemnya Bronfennbrener, yakni sekolah, termasuk di dalamnya lingkungan dan iklim sekolah.

Peterson, Buser \& Westburg (2010) mengemukakan bahwa pada masingmasing dimensi delinquency ada yang berhubungan langsung maupun tidak langsung. Attachment dan involvement keluarga berhubungan langsung dengan penyalahgunaan napza. Namun dukungan sosial tidak berhubungan langsung dengan resiko tinggi delinquency dan penyalahgunaan napza, melainkan ada mediatornya,yaitu self esteem dan involvement keluarga. Model yang ditawarkan oleh Peterson, Buser, \& Westburg (2010) tersebut fit untuk menggambarkan keterikatan antara attachment anak dengan orang tuanya, involvement dengan orang tuanya, dukungan social, self-esteem, penyalahguna napza dan resiko tinggi perilaku delinquency lainnya.

Berdasarkan social control theory (Hircshi dalam Ingram dkk, 2007) menyatakan bahwa seseorang yang rendah atau retak dengan bonding social (keluarga, teman, sekolah dan media) akan mengalami masalah perilaku, dalam hal ini disebut delinquency. Seorang anak yang lekat dengan orang tuanya akan mampu mengurangi bentuk penyimpangan perilaku, termasuk delinquency. Apabila objek lekatnya (bond) yang berada di luar keluarga mengarah pada aktifitas yang kurang baik, maka akan memperparah perilakunya, mengarah pada delinquency yang serius.

General strain theory; Moon, Blurton, \& McClueskey, 2008), menyebutkan strain sebagai stressor yang berasal dari emosi negatif (seperti kemarahan) yang 
tidak dapat ditoleransi dan tidak dapat dikelola lagi. Misalnya seorang anak yang membutuhkan barang tertentu ia akan mempunyai keinginan mencari uang untuk memenuhi keinginannya tersebut. Selain itu, tampak seorang yang berperilaku merusak karena merasa tertindas, mengapa seorang anak memakai napza karena ingin melepaskan kondisi yang tertekan.

Agnew (dalam Moon, Blurton, \& McClueskey, 2008; Froggio, 2007; Cernkovich, Lanctot, \& Giodarno, 2008; Mazerolle \& Maahs, 2000; Katz, Dunham, \& Zimmerman, 1997) mengemukakan terdapat tiga sumber utama strain, yaitu : 1) situasi yang menghalangi pencapaian tujuan disebut juga sebagai classic strain theory, 2) situasi yang menjauhkan dari tujuan, dan 3) situasi yang menghasilkan emosiemosi negatif. Paparan Agnew (dalam Moon Blurton, \& McClueskey, 2008) selanjutnya adalah mengenai objective strain yang menjadi fokus dalam teori ini, yaitu peristiwa atau kondisi yang tidak diterima, seperti tekanan fisik, kesulitan finansial dan korban tindakan kriminalitas.

Agnew (Regoli dan Hewitt, 2003) menyatakan dengan general strain theory akan menambah jumlah anak yang frustrasi, yang dapat menyebabkan delinquency. Frustrasi merupakan kondisi emosi negatif yang seharusnya membutuhkan penyelesaian. Jadi apabila kondisi ini tidak dapat terselesaikan akan berlanjut menjadi penyimpangan perilaku ataupun masalah emosional yang lain.

Jadi inti dari General Strain Theory adalah "strain" yang akan meningkatkan delinquency. Paparan Mezerolle \& Maahs (2000) aspek kunci dari GST adalah delinquency sebagai respon perilaku dapat dipikirkan kembali ketika kondisi tersebut sedang terjadi. Dimana yang dapat menjadi faktor adalah : 1) moral belief, yaitu sebagai aspek kontrol internal, 2) keterlibatan dengan sesama teman yang delinquent, yaitu sebagai proses belajar sosial dan model yang dapat ditiru, dan 3) kecenderungan penyimpangan perilaku, dengan ciri-ciri self-control rendah, impulsif dan tendensi antisosial. Paparan lanjutan dari Mazerolle \& Maahs (2000) menyatakan bahwa "strain" dan delinquency mempunyai hubungan yang sistematis dan linier. Dengan strain yang dialami oleh seorang anak akan meningkat delinquency-nya, baik pada kelompok sesama teman yang delinquent maupun kecenderungan berperilaku menyimpang. Yang tidak linier adalah pada moral-belief.

Pada kajian strain ini akan dibahas juga economic strain theory, Asumsi pada teori ini merupakan hasil tekanan ekonomi yang dialami, termasuk di dalamnya adalah uang saku yang dimiliki seorang anak (financial), kehilangan barang yang dimiliki, struktur keluarga yang kacau, seperti perceraian, dan pendapatan keluarga yang menimbulkan ketidakpuasan. Kondisi ini akan menimbulkan delinquency seperti 
sebagai bandar narkotika, pada usia sekolah mereka akan menunjukkan perilaku membolos, penyalahgunaan napza dan tekanan emosional (Wester, MacDonald, \& Lewis (2008); Wadsworth, 2000). Pada paparan GST ini dapat disimpulkan bahwa seseorang merespon terhadap kondisi dirinya secara individual maupun faktor yang berasal dari lingkungannya. strain merupakan mediating ketika emosi negatif muncul. Contoh ketika seorang anak di dalam keluarga sedang terjadi konflik, maka akan munculemosi negatif

Berdasar kerangka teoritis di atas diajukan hipotesis sebagai berikut:

1. Semakin baik iklim keluarga akan mampu menurunkan delinquency

2. Semakin tinggi keterlibatan pada aktivitas sosial pada hal yang negatif akan meningkatkan delinquency

3. Delinquency meningkat dari delinquency ringan ke delinquency berat

4. Delinquency akan semakin serius dengan adanya "strain"

5. Model social control theory dan general strain theory merupakan kontinuitas delinquency

\section{Metode Penelitian}

Subjek yang berasal dari SMP Muhammadiyah 1 Sragen dan SMA Negeri 2 Sragen, kelas 7 - 12, sebanyak 182 anak, dengan usia rata-rata 15,41 tahun. Sampel ini terdiri dari 112 (61,5\%) laki-laki dan 70 (38,5\%) perempuan.

Data dikumpulkan dengan metode self-report dari angket yang diberikan. Angket yang diberikan terdiri dari : Iklim keluarga, terdiri dari attachment parent dan involvement parent, dengan alternatif respon 0 (tidak pernah), 1 (jarang), 2 (kadang-kadang), dan 3 (sering), dan 4 (selalu). Sosial, terdiri dari involvement peers, attachment teacher, dan attachment media, dengan alternatif respon 0 (tidak pernah), 1 (jarang), 2 (kadang-kadang), dan 3 (sering), dan 4 (selalu). Delinquency ringan, yang terdiri membolos dan kebut-kebutan, dengan alternatif respon 0 (tidak pernah), 1 (jarang), 2 (kadang-kadang), dan 3 (sering), dan 4 (selalu). Delinquency berat, yang terdiri mencuri dan berjudi, dengan alternatif respon 0 (tidak pernah), 1 (jarang), 2 (kadang-kadang), dan 3 (sering), dan 4 (selalu).

\section{Hasil dan Pembahasan}

Matriks Korelasi antar variabel menunjukkan interkorelasi antara keterlibatan dengan teman dan dari media berhubungan dengan kebut-kebutan $(r=0.149, \mathrm{p}<0.05$ dan $r=0.239, p<0,01)$. Uang saku juga berhubungan dengan membolos dan kebut- 
kebutan $(r=0.202, p<0.01$ dan $r=0.294, p<0.01)$. Selain itu uang saku juga berhubungan dengan media $(r=0.265, p<0.01)$.

Tabel 2.

Statistik Deskriptif

\begin{tabular}{lrr}
\hline \multicolumn{1}{c}{ Variabel } & Mean & Std. Deviation \\
\hline Iklim Keluarga & & \\
$\quad$ Attachparent & 2.73 & 1.190 \\
$\quad$ Involvparent & 2.36 & 1.179 \\
Sosial & & \\
$\quad$ Involvpeers & 1.18 & 1.187 \\
$\quad$ Attachteacher & 2.35 & .871 \\
$\quad$ Attachmedia & 1.29 & 1.247 \\
Delinquency Ringan & & \\
$\quad$ Membolos & .32 & .663 \\
$\quad$ Kebut-kebutan & .63 & 1.068 \\
Delinquency Serius & & \\
$\quad$ Mencuri & .19 & .534 \\
$\quad$ Berjudi & .08 & .362 \\
Strain & & \\
$\quad$ Uang saku & 1.81 & .706 \\
Umur & 15.41 & 1.483 \\
\hline
\end{tabular}

Structural equation modeling dengan menggunakan generali ed least squares estimates diperoleh hasil seperti pada gambar 1.

Pada gambar 1, kriteria model fit ditunjukkan dengan nilai Chi-square $=33.546$, Degrees of freedom $=27$, Probability level $=.180 ; p>0.05$. Model Ayang berasal dari social control theory, dengan mempertimbangkan pertimbangan fit lainnya, yaitu $\mathrm{GFI}=0.959 ; \mathrm{AGFI}=0.931 ; \mathrm{CFI}=0.901$, dan $\mathrm{RMSEA}=0.037$. Variabel dependen memiliki parameter yang seimbang dan sama sekali tidak mengalami modifikasi model melalui modification indicies (MIs). Dapat disimpulkan bahwa model persamaan struktural, model A tersebut adalah fit. 


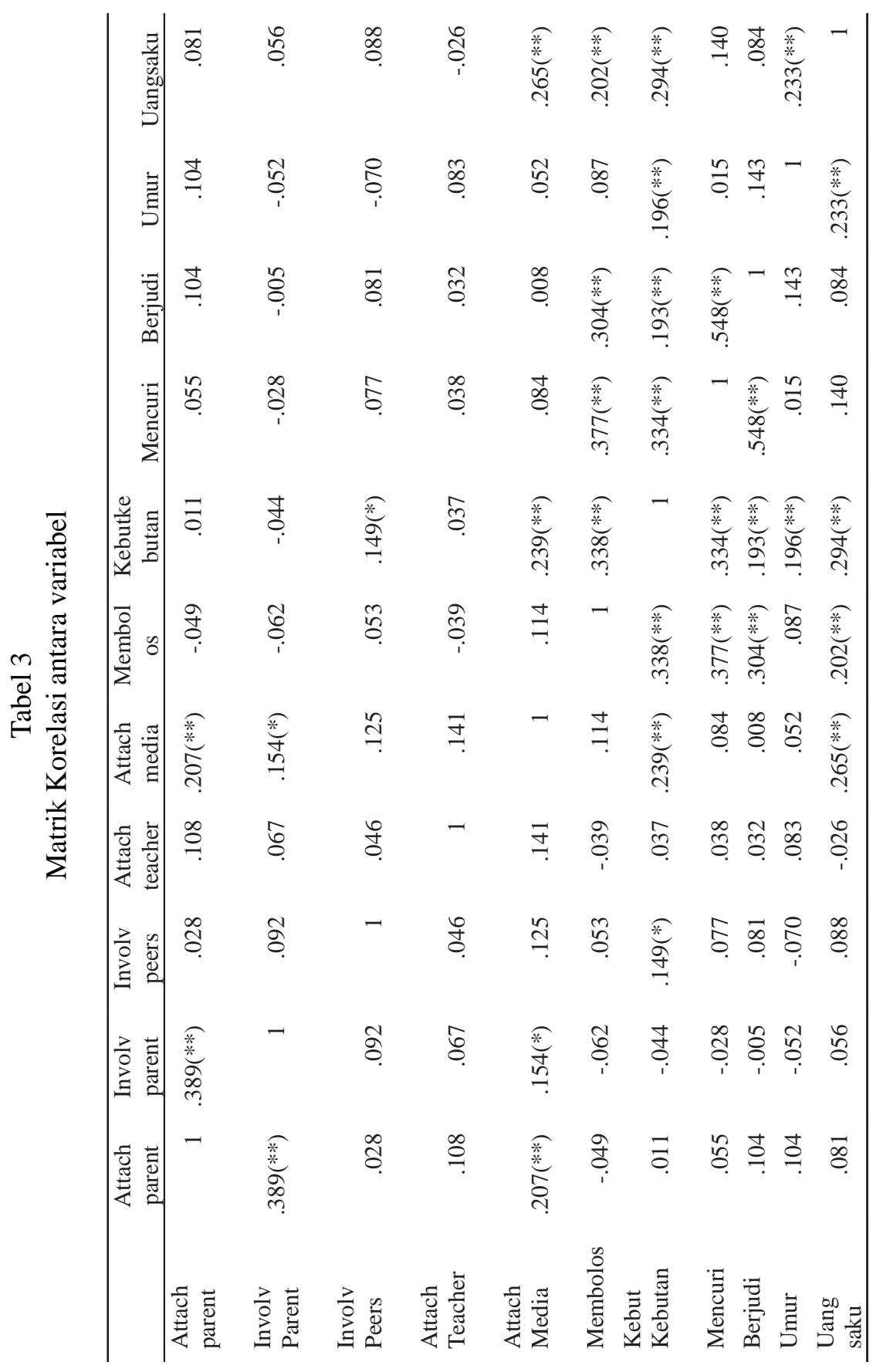


Structural equation modeling dengan menggunakan generali ed least squares estimates untuk menguji kontinuitas delinquency dengan dasar teori GST terpapar pada gambar 2.

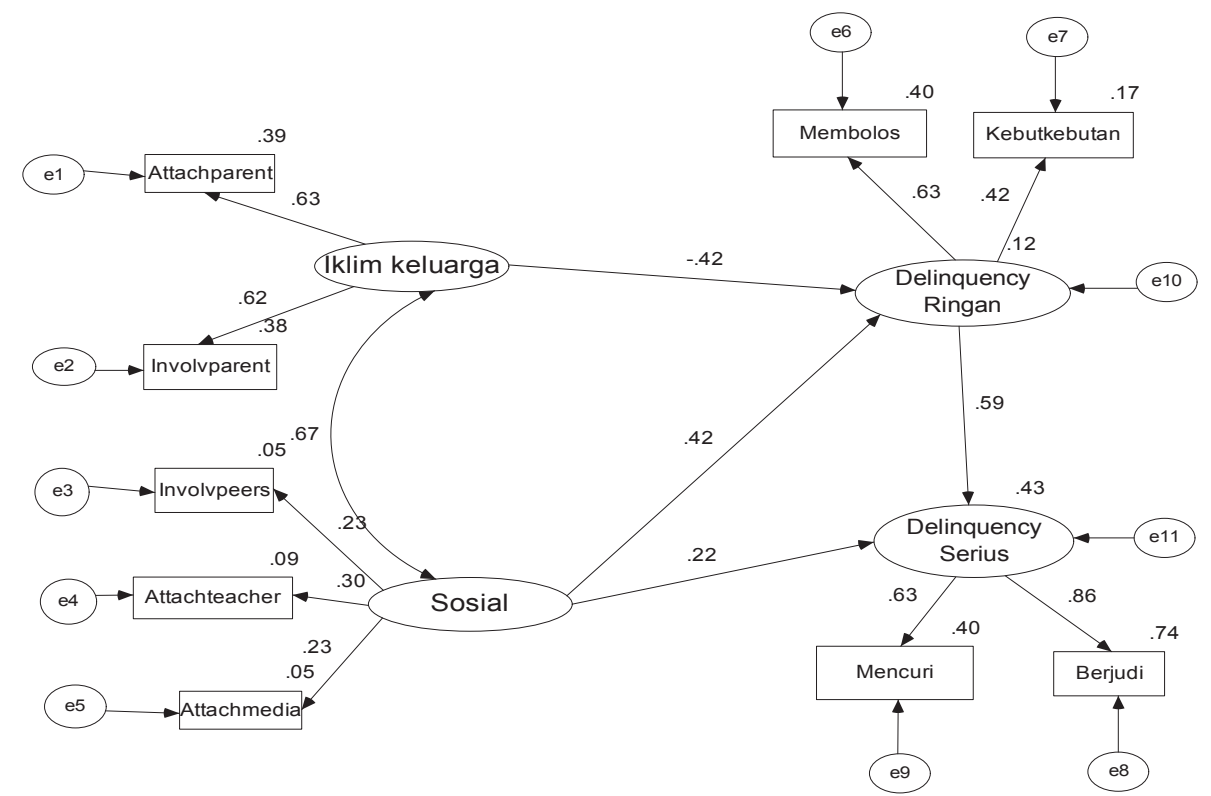

Gambar 1. Model A

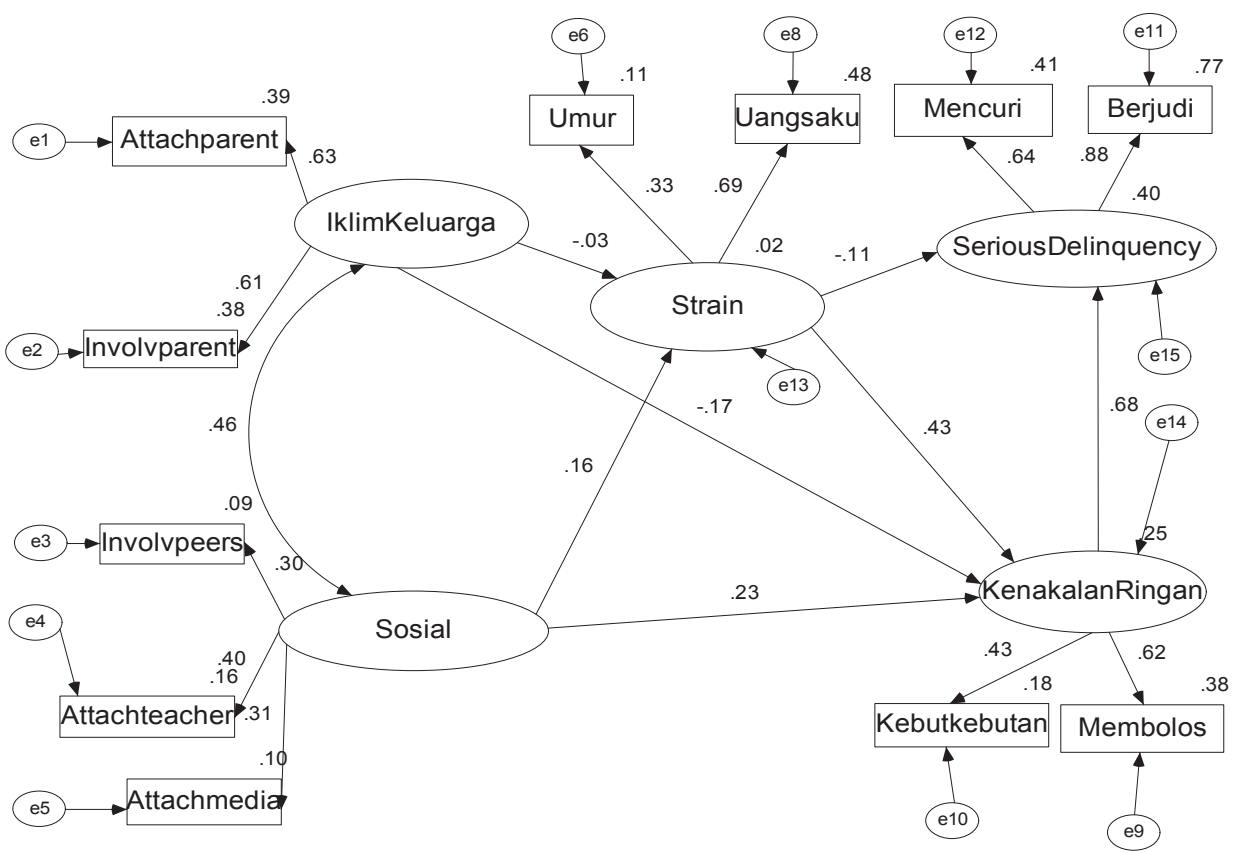

Gambar 2. Model B 
Pada gambar 2, kriteria model fit ditunjukkan dengan nilai Chi-square $=57.933$, Degrees of freedom $=42$, Probability level $=.052 ; \mathrm{p}>0.05$. Model B yang berasal dari general strain theory, dengan mempertimbangkan pertimbangan fit lainnya, yaitu GFI $=0.942$; AGFI $=0.909 ;$ CFI $=0.802$, dan RMSEA = 0.046. Variabel dependent memiliki parameter yang seimbang dan sama sekali tidak mengalami modifikasi model melalui modification indicies (MIs). Dapat disimpulkan bahwa model persamaan struktural, model $\mathrm{B}$ tersebut adalah fit.

Tabel 4.

Perbandingan Goodness of Indexes pada model A dan model B

\begin{tabular}{cccccccc}
\hline Model & Chi-square & df & $\mathrm{p}$ & GFI & AGFI & CFI & RMSEA \\
\hline A & 33.546 & 27 & 0.180 & 0.959 & 0.931 & 0.901 & 0.037 \\
B & 57.933 & 42 & 0.052 & 0.942 & 0.909 & 0.802 & 0.046 \\
\hline
\end{tabular}

Pada hasil di atas, model berdasarkan social control theory dan general strain theory yang digunakan sebagai salah satu teori untuk mengembangkan model menunjukkan bahwa ada hubungan negatif antara iklim keluarga dengan delinquency, khususnya delinquency ringan (angka estimasinya 0,42 dan 0.17). Hal ini sangat konsisten dengan apa yang dikemukakan Hirschi (Booth, Farrell, \& Varano, 2008; Wester MacDonald, \& Lewis, 2008; Ingram, Patchin, McCluskey, \& Bynum, 2007; Mason \& Windle, 2002) bahwa iklim keluarga yang baik dengan membangun kelekatan dan terlibat dengan anak akan mampu mencegah delinquency.

Iklim keluarga yang baik, terjadi ketika orang tua melakukan supervisi, komunikasi, dan mau melibatkan serta anak merasa terlibat dalam aktifitas kebersamaan dengan orang tua menjadi faktor yang dapat mencegah terbentuknya delinquency. Selain dari keluarga seorang anak juga mempunyai lingkungan sosial, di luar lingkungan keluarga. Anak akan mempunyai teman, masuk dalam institusi pendidikan, dan kecanggihan IT menjadi media yang dapat dinikmati oleh anak. Kelekatan dan keterlibatan seorang anak pada lingkungan sosial yang kurang positif akan semakin meningkatkan meningkatkan delinquency, apalagi dengan iklim keluarga yang kurang baik seperti paparan sebelumnya, lingkungan sosial akan semakin memperparah delinquency-nya.

Pada teori kontrol sosial pengaruh keluarga dan sosial memberi estimasi yang sama besarnya terhadap delinquency. Jadi sosial belum tentu berpengaruh lebih besar terhadap delinquency. Dapat dilihat pada gambar 2 memberi kontribusi yang sama besarnya. Dalam hal ini dapat dijelaskan apabila sosial membentuk kontrol 
yang kurang baik pada anak dapat dicounter dengan iklim keluarga yang baik.

Delinquency akan terjadi peningkatan, apabila anak sudah melakukan bentuk delinquency yang ringan. Seorang anak yang sudah melakukan delinquency akan mendapat label sebagai anak nakal. Menurut Bernburg \& Krohn (dalam Bernburg, Krohn, \& Rivera, 2006) menyatakan bahwa labeling dalam konteks delinquency merupakan konsekuensi dalam struktur sosial, yang merupakan pendorong untuk memindahkan seseorang pada kelompok yang mengalami penyimpangan tersebut. Contohnya, label "nakal" yang diberikan pada anak, maka anak akan menuju dan menempatkan pada kelompok anak nakal tersebut. Hal tersebut juga dikuatkan kembali oleh Bernburg, Krohn, \& Rivera, (2006) yang menyimpulkan tiga hal, yaitu: 1) labeling akan semakin meningkatkan keterlibatan anak pada kelompok yang mengalami penyimpangan perilaku/delinquency, 2) labeling akan lebih meningkatkan kemungkinan anak mengalami delinquency yang serius, dan 3) labeling menjadi social learning pada bentuk delinquency lain.

Asumsi lain menyatakan bahwa labeling theory berdasarkan asumsi bahwa persepsi negatif yang muncul akan berkembang menjadi konsep diri yang negatif, sehingga memudahkan seorang anak untuk terlibat pada bentuk delinquency yang lebih berat. Labeling ada dua, yaitu formal dan informal. Labeling formal berasal dari lembaga kontrol sosial, sedangkan labeling informal berasal dari orang tua, guru, dan teman. Ternyata labeling yang diberikan orang tua dan guru hubungannya sangat kuat dalam memunculkan delinquency (Adams, Robertson, Ray, \& Ray, 2003).

Delinquency adalah perilaku. Teori perilaku menyatakan bahwa selain dipengaruhi oleh faktor luar yang sudah dipaparkan oleh teori kontrol sosial, sekaligus sebagai kelemahan teori tersebut. juga dipengaruhi oleh kondisi dari anak sebagai individu, sebagai pelaku delinquency. Dalam hal ini faktor dari diri anak, yang tidak muncul pada teori kontrol sosial. General strain theory (GST) memaparkan faktor dari anak yang berupa "strain".

Kontrol sosial merupakan proses yang dinamis. Seorang anak yang kurang atau tidak mampu mengikuti dinamisasi kontrol sosial, baik yang berasal dari keluarga, teman, sekolah, maupun media akan mengalami frustrasi. Apalagi ketika anak mendapat tuntutan dari tugas perkembangan atau tugas dalam sistem kontrol sosial yang tidak dapat ditunaikan. Maka anak akan mengalami "strain". Misalnya anak di dalam keluarga yang kebetulan status ekonominya tergolong rendah, dengan uang saku yang kurang. Anak menemukan lingkungan sosial yang lebih tinggi dari status ekonomi keluarganya. Anak akan menjauh dari keluarganya dan lebih lekat pada 
lingkungan sosialnya.

Pada setting keluarga, akan melibatkan orang tua, ayah dan ibu serta saudara. Pada pihak sekolah akan melibatkan guru, iklim di sekolah, aturan yang berlaku di sekolah, dan yang berkaitan lainnya. Sedangkan teman sebaya adalah orang lain yang membutuhkan kepedulian. Brank dkk (2008) melakukan percobaan menurunkan delinquency dengan memperbaiki hubungan dengan orang tua dan teman-temannya. Penelitian ini melibatkan multiagency, dimana anak tinggal, dimana temannya tinggal, apabila orang tua diminta data dari pihak kepolisian, sekolah untuk mencari informasi mengenai pelanggaran apa yang pernah dilakukan anak.

Data yang diperoleh Purwandari (2005) menunjukkan penyalahgunaan napza berawal dari mempunyai masalah, frustrasi dan stres yang dialami oleh anak. Kondisi anak seperti yang dikemukakan oleh Agnew (dalam Mazerolle \& Maahs, 2000) dalam kondisi "strain" akan meningkatkan delinquency. Strain akan direspon secara nyata oleh anak dalam bentuk delinquency.

Social control theory dan general strain theory merupakan dua teori yang dapat menjelaskan dinamika delinquency. Berdasarkan kedua teori tersebut kontinuitas delinquency dapat dilihat. Namun meskipun demikian, pada uji model tersebut social control theory lebih tinggi nilai goodness of indexes apabila dibandingkan dengan general strain theory.

Kelemahan dalam penelitian ini adalah jumlah subjek perlu ditambahkan lebih besar lagi dan lebih komprehensif. Selain itu model belum dibandingkan antara lakilaki dan perempuan. Seperti yang diutarakan oleh Cernkovich, Lanct $\mathrm{t} \&$ Giordano (2008); Booth, Farrell \& Varano (2008) yang menyatakan bahwa laki-laki dan perempuan pada delinquency ini berbeda.

Kondisi sosial negara Indonesia berbeda dengan negara lain. Hirschi's theory yang merupakan aplikasi dari teori ekologi dari Bronfennbreuner menunjukkan bahwa ada mikrosistem, mesosistem, eksosistem, dan makrosistem. Dimensi social yang dianut dalam keluarga, sekolah, bersosialisasi adalah hal yang penting untuk diperhatikan. Idiologi yang dianut serta kepercayaan yang diyakini akan membawa bagaimana munculnya interaksi (Barry, dkk, 2008; Booth, dkk, 2008).

Model pencegahan delinquency perlu memperhatikan idiologi yang dianut oleh individu dalam masyarakat tersebut. Seperti apa yang dimaksud dengan delinquency, kriteria delinquency dan hal-hal lain yang berkaitan dengan itu. Selain paparan tersebut di atas, menurut penulis sebuah model yang tergambar belum merupakan sebuah alur yang tersistematisasi. 


\section{Simpulan}

Berdasarkan paparan di atas dapat diambil kesimpulan : Iklim keluarga yang baik akan mampu mengurangi delinquency. Sosial belum tentu memberi pengaruh yang kuat pada delinquency. Delinquency akan berbentuk kontinuitas, dari yang ringan sampai serius. Strain akan memberi pengaruh yang lebih besar pada kemunculan delinquency. Model A dan model B dapat menjelaskan kontinuitas delinquency, namun dengan strain belum tentu modelnya lebih baik.

\section{Daftar Pustaka}

Adams, M.S., Robertson, C.T., Ray, P. G, \& Ray, M. C. (2003). Labeling dan delinquency. Adolescence, Vol. 38, No. 149, Spring 2003: 171186.

Anganti, N. R. A., Purwandari, E., \& Purwanto, Y. (2010). Pola delinquency penyalahguna napza di surakarta. Laporan Penelitian Fundamental Research Dikti.

Barry, C, Frick, P. J., \& Grafeman, S. J. (2008). Child versus parents reports of parenting practice. Assessment, Vol. 15, No.3, September 2008: 294 303.

Bernburg, J, G., Krohn, M. D., \& Rivera, C. J. (2006). Official labelling, criminal embeddedness, subsequent delinquency. A longitudinal test of labelling theory. Journal of Research in Crime and Delinquency. Vol. 43, No. 1. February 2006: 6788 .

Booth, J.A., Farrel, A., \& Varano, S. P. (2008). Social control, serious delinquency, and risk behavior a gender analysis. Crime \& Delinquency, Vol. 54, No. 3 July 2008, 423456.

Brank, E, Lane, J., Turner, S., Fain, T., \& Sehgal, A. (2008). An experimental juvenile probation program: Effects on parent and peer relationships. Crime \& Delinquency. Volume 54, Number 2, April 2008: 193-224.

Cernkovich, S. A., Lanctot, N, \& Giodarno, P. C. (2008). Predicting adolescent and adult antisocial behavior among adjudicated delinquent female. Crime \& Delinquency, Vol. 54, No.1, January 2008: 333.

Cookston, J.T. (1999). Parental supervision and family structure: Effects on adolescent problem behaviors. Journal of Divorce and Remarriage, Vol. 32 (1/2), 107120. 
Froggio, G (2007). Strain and juvenile delinquency critical review: of Agnew's General Strain Theory. Journal of Law and Trauma. $12: 383418$.

Ingram, J. R, Patchin, J. W, McCluskey, J. D., \& Bynum, T. S. (2007). Parents, friends, and serious delinquency: An examinationof direct and indirect effect among at-risk early adolescents. Criminal Justice Review, Vol.32, No. 4, December $2007: 380400$.

Katz, J. S., Dunham, R. \& Zimmerman, R. (1997). Family structure versus parental attachment in controlling adolescent deviant behavior: A Social control model. Adolescence, Vol. 32, No.125, 199 215. Spring. Libra Publisher, Inc., 3089C Clairemont Dr,. Suite 383, Sn Diego, CA92117

Masngudin HMS. 2004. Kenakalan remaja sebagai perilaku menyimpang hubungannya dengan keberfungsian sosial keluarga. Kasus di Pondok Pinang pinggiran kota metropolitan Jakarta. http://www.depsos.go.id/ Balatbang/Puslitbang\%20UKS/2004/Masngudin.htm

Mason, W. A. \& Windle, M. (2002). Gender, self-control, and infomal social control in adolescence : A test of three models of continuity of delinquent behavior. Youth Society, Vol. 33 No. 4, June 2002: 479514.

Mazerolle, P\& Maahs, J. (2000). General strain and delinquency: An alternative examination of conditioning influences. Justuce Quarterly. Vol. 17, No. 4, December 2000: 753777.

Moon, B., Blurton, D., \& McClueskey,J. D. (2008). General strain theory and delinquency: Focusing on the influences of strain characteristics on delinquency. Crime \& Delinquency. Vol. 54, N0 4, 582613.

Ngai, N. P \& Cheung, C. K. (2005). Predictors of the likehood of delinquency: A study of marginal youth in Hong Kong China. Youth \& Society, Vol. 36 No. 4, June 2005 445-470

Peterson, C.H; Buser, T.J \& Westburg, N.G. (2010). Effects of familial attachment, social support, involvement, and self-esteem on youth substance use and sexual risk taking. The Family Journal: Counseling and Therapyfor Couples and Families, 18 (4) : 369376.

Purwandari, E. (2007). Orientasi nilai-nilai hidup: Proses pengambilan keputusan berhenti mengkonsumsi NAPZA. Jurnal Penelitian Humaniora, Vol. 8, No. 2, Agustus 2007, 148165.

Purwandari, E. (2005). Memori emosional remaja yang sedang menjalani rehabilitasi 
NAPZA. Jurnal Penelitian Humaniora Vol. 6, No. 2, Agustus 2005, 130143.

Regoli, R \& Hewitt, J. (2003). Delinquency in Society. New York: McGraw-Hill

Tracy, P. E., Leonard, K \& James, S. A. (2009). Gender differences in delinquency and juvenile justice processing: Evidence from national data. Crime \& Delinquency, Volume 55, Number 2 April 2009: 171-215.

Wadsworth, T. (2000). Labor markets, delinquency, and social control theory: An empirical assessment of the mediating process. Social Forces, March 2000, 78 (3) : $1041 \quad 1066$

Wester, K. A, MacDonald, C. A., \& Lewis,T. F. (2008). A glimpse into the lives of nine youth in correctional facility: Insight into theories of delinquency. Journal of Addictions \& Offender Counseling • April $2008 \bullet$ Volume 28

Wiatrowski, M. D., Griswold, D. B., \& Roberts, M. K. (1981). Social control theory and delinquency. American Sociological Review, Vol. 46 (October: 525 541). 